\title{
Reaksi Pasar Sektor Properti dan Real Estat atas Penjualan Perdana Mega Proyek Meikarta
}

\author{
Ni Ketut Modi Pitriani1 \\ Fakultas Ekonomi dan Bisnis \\ Universitas Udayana, Indonesia \\ Email: modifitriani@gmail.com
}

\author{
Dewa Gede Wirama ${ }^{2}$ \\ Fakultas Ekonomi dan Bisnis \\ Universitas Udayana, Indonesia
}

\begin{abstract}
ABSTRAK
Penjualan perdana (launching) mega proyek Meikarta mendapat respon positif dari masyarakat, terbukti dengan terjualnya sebanyak 17.435 unit apartemen pada hari penjualan perdana tersebut. Karena skalanya yang sangat besar, mega proyek Meikarta berpotensi menggairahkan kembali sektor properti yang saat itu sedang lesu. Penelitian ini bertujuan untuk menganalisis muatan informasi (information content) proyek Meikarta khususnya pada perusahaan yang berada dalam sektor properti dan real estat. Muatan informasi diidentifikasi berdasarkan respon pasar atas peristiwa penjualan perdana mega proyek Meikarta. Selanjutnya, respon pasar diukur dengan return abnormal menggunakan market adjusted model dengan event window selama lima hari di sekitar tanggal launching. Sampel penelitian berjumlah 48 perusahaan pada sektor properti dan real estat. Hasil analisis menunjukkan bahwa tidak terdapat respon pada sektor properti dan real estat di Indonesia atas peristiwa penjualan perdana mega proyek Meikarta, sehingga disimpulkan bahwa peristiwa tersebut tidak memiliki muatan informasi.
\end{abstract}

Kata Kunci: $\quad$ Meikarta; Sektor Properti dan Real Estat; Muatan Informasi; Reaksi Pasar; Return Abnormal.

\section{Market Reaction Of Property And Real Estate Sector To Launching Meikarta Mega project}

\begin{abstract}
The launching of Meikarta mega project gained positive response from customers. As many as 17,435 apartment units was sold on the day the project was launched. Because of its huge scale, the Meikarta has the potential to boost the property and real estate sector that was down at the time. The aim of this research is to analyze the information content of Meikarta project, especially for firms in the property and real estate sector. The information content is to be identified by market response, which in turn to be measured by abnormal return using marketadjusted model with five-day event windows around the launching date. Sample consists of 48 firms in the property and real estate sector. The results of the analysis show that there is no statistically significant market response to the launching of Meikarta project. Therefore, it is concluded that the Meikarta project does not have any information content.
\end{abstract}

Keywords: Meikarta; Property and Real Estate Sector; Information Content; Market Reaction; Abnormal Return.

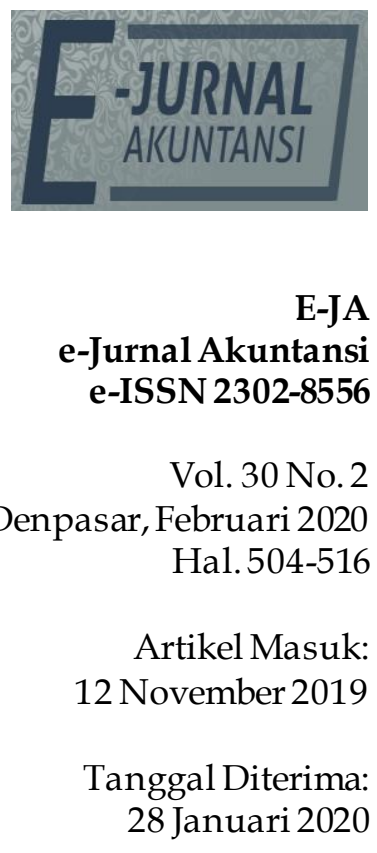

28 Januari 2020 


\section{PENDAHULUAN}

Meikarta merupakan proyek besar Lippo Group yang masuk dalam unit bisnis properti yang dikembangkan oleh PT Lippo Cikarang Tbk, yang tercatat sebagai salah satu perusahaan publik di Indonesia. Meikarta adalah langkah lanjutan dari serangkaian pengalaman Lippo Group dalam membangun kota mandiri seperti Orange County di Bekasi, Jawa Barat; Holland Village di Cempaka Putih, Jakarta Pusat; dan Millenium Village di Tangerang, Banten. Lokasi Mega proyek Meikarta berada di daerah yang berkembang pesat pada bidang industri manufaktur, di Cikarang, Jawa Barat. Mega proyek Meikarta dirancang sebagai kota pusat pertumbuhan perekonomian modern berbasis industri dan perdagangan nasional maupun internasional (Mayanti, 2018).

Meikarta dianggap dapat menjawab kebutuhan masyarakat akan hunian baru yang bersih dan modern. Lippo Group berambisi bahwa mega proyek Meikarta dapat menjadi sebuah kota berskala internasional. Konsep yang dikembangkan oleh Lippo Group untuk Meikarta sudah terencana dengan baik. Hal tersebut tampak pada konsep pembangunan kota yang dirancang tertata rapi dengan sarana dan prasarana yang lengkap, mulai dari transportasi, parkir, dan sarana utilitas lainnya. Tidak hanya itu, Meikarta juga memberikan ruang terbuka hijau yang sangat luas dan dapat diakses secara gratis oleh penghuni dan masyarakat lainnya (Lutfiana, 2018).

Total nilai proyek pembangunan kota mandiri Meikarta yang dikembangkan PT Lippo Cikarang Tbk ini, mencapai lebih dari Rp278 triliun. Mega proyek Meikarta rencananya dibangun di atas lahan seluas 2.200 hektar dengan tahap awal pembangunan mencapai 500 hektar di Cikarang, yang terletak diantara dua kota metropolitan yaitu Jakarta dan Bandung. Proyek Meikarta digadang-gadang sebagai kota mandiri terlengkap di Asia Tenggara yang memiliki 100 gedung pencakar langit yang masing-masing memiliki 35 sampai 46 lantai terdiri dari apartemen, rumah sakit, office tower, shopping mall, perumahan, sekolah, dan lain-lain. Kota Meikarta diharapkan mampu menjadi solusi untuk mengatasi masalah over-population di kota-kota besar seperti Jakarta dan Bandung.

Penjualan perdana mega proyek Meikarta dilaksanakan pada Sabtu, 13 Mei 2017 di Maxxbox Orange County, Bekasi, Jawa Barat. Pada penjualan perdana tersebut berhasil terjual sebanyak 16.800 unit apartemen, sampai berita tersebut diterbitkan (Himawan, 2017). Tim rekor dari Museum Rekor Dunia Indonesia (MURI) pada Senin, 15 Mei 2017 dengan nomor rekor 7.842 menetapkan launching mega proyek Meikarta yang diselenggarakan pada tanggal 13 Mei 2017 sebagai penjualan unit apartemen terbanyak dalam sehari yakni, sejumlah 17.435 unit dalam sehari.

Keberhasilan penjualan perdana mega proyek Meikarta terjadi di tengah lesunya sektor properti dan real estat di Indonesia. PT Agung Podomoro Land Tbk mencatat penurunan penjualan mencapai 31,9\% dan PT Summarecon Agung Tbk mengalami penurunan penjualan hingga 50\% dibandingkan kuartal I-2014, Sementara pra penjualan PT Alam Sutera Tbk juga turun 29\% di awal tahun 2015 (Fitra, 2015).

Pertumbuhan yang rendah di sektor properti membuat indeks harga saham sektor ini turun pada awal tahun 2015 hingga berada pada level 532,96. 
Indeks harga saham sektor properti di Bursa Efek Indonesia (BEI) sempat naik mencapai level paling tinggi di akhir Februari 2015 ke posisi 580,71. Kinerja sektor ini melemah menyebabkan indeks sahamnya kembali menurun, hingga menyentuh level 496,91 pada penutupan perdagangan di bulan Mei 2015. Ketua umum persatuan perusahaan Real Estat Indonesia (REI) menyatakan bahwa sebagai akibat dari kondisi ekonomi berupa melemahnya nilai tukar rupiah terhadap dolar saat itu, ikut berdampak pada rendahnya daya beli masyarakat di sektor properti. Penundaan rencana ekspansi dari pengembang juga dipengaruhi kebijakan yang dikeluarkan oleh pemerintah dan Bank Indonesia (BI).

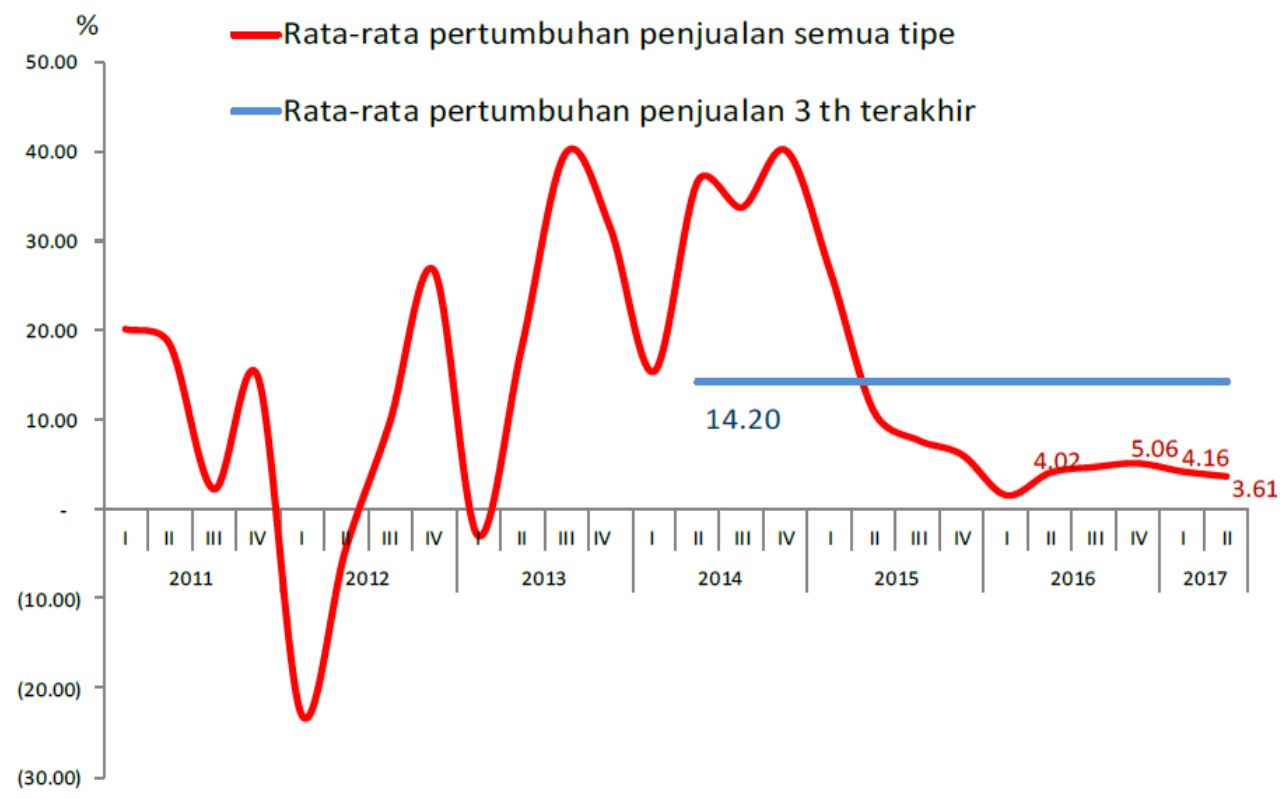

\section{Gambar 1. Grafik Pertumbuhan Penjualan Properti Residensial} Sumber: Bank Indonesia, 2017.

Penjualan unit properti mengalami perlambatan sejak kuartal I tahun 2015 hingga kuartal II tahun 2017. Hal tersebut dapat dilihat dari data survei harga properti residensial yang dilakukan oleh Bank Indonesia (lihat Gambar 1). Mulai awal kuartal II tahun 2015 sampai dengan akhir kuartal II tahun 2017, penjualan properti berada di bawah rata-rata penjualan selama tiga tahun terakhir. Jadi, dapat dikatakan secara keseluruhan dari awal tahun 2015 hingga tahun 2017 keadaan sektor properti dan real estat sedang lesu.

Di tengah lesunya keadaan sektor properti dan real estat di Indonesia tersebut, penjualan perdana mega proyek Meikarta mendapat respon positif dari masyarakat. Hal tersebut dapat memengaruhi pandangan investor mengenai keberhasilan proyek Meikarta kedepannya. Penjualan perdana mega proyek Meikarta dipilih untuk diteliti reaksi pasarnya karena dianggap merupakan tahap awal serta waktu yang paling tepat untuk melihat reaksi investor mengenai mega proyek Meikarta. Peristiwa ini menunjukkan bahwa mega proyek Meikarta merupakan salah satu gebrakan pada sektor properti dan real estat, yang dipelopori PT Lippo Cikarang Tbk, dapat menjadi langkah awal perkembangan dan kebangkitan sektor properti dan real estat di Indonesia. Dampak positif Meikarta berpotensi menambah minat investor tidak hanya 
kepada PT Lippo Cikarang Tbk melainkan kepada semua perusahaan di sektor properti dan real estat.

Penelitian ini bertujuan menganalisis apakah penjualan perdana mega proyek Meikarta memperoleh respon positif dari investor pasar modal, khususnya pada sektor properti dan real estat di Indonesia. Respon tersebut diharapkan terjadi karena keberhasilan penjualan perdana mega proyek Meikarta merupakan suatu kejadian yang dapat mengarahkan pandangan publik bahwa sektor properti dan real estat secara keseluruhan mulai berkembang kembali.

Pasar modal yang baik ialah pasar modal yang efisien. Pasar dikatakan efisien jika harga saham yang diperdagangkan merefleksikan semua informasi yang tersedia. Sebagai konsekuensinya, harga akan langsung bereaksi tanpa adanya bias terhadap informasi baru (Fama, 1970). Hartono (2017:605) menyatakan bahwa bagaimana suatu pasar bereaksi terhadap suatu informasi untuk mencapai harga keseimbangan yang baru merupakan hal yang penting. Jika harga keseimbangan pasar diperoleh dengan cepat maka penyesuaian harga di masa depan sulit ditebak dan sulit bagi investor untuk mendapat abnormal return (Ziobrowski et al., 2011).

Riset kandungan informasi bermanfaat untuk menguji apakah suatu event mempunyai pengaruh terhadap harga saham pada waktu event terjadi (Watts \& Zimmerman, 1986). Foster (1986) menyatakan kandungan informasi berarti realise pengumuman yang menyebabkan revisi dalam distribusi return sekuritas. Terdapat tiga faktor yang mempengaruhi kandungan informasi suatu pengumuman, yaitu ekspektasi pasar modal terhadap kandungan (content) dan waktu (timing) suatu pengumuman, implikasi suatu pengumuman terhadap distribusi return sekuritas di waktu yang akan datang, kredibilitas sumber informasi.

Suatu studi peristiwa (event study) berguna untuk menguji kandungan informasi dari suatu pengumuman dan digunakan untuk menguji efisiensi pasar bentuk setengah kuat, kedua pengujian tersebut merupakan dua pengujian yang berbeda (Fama, 1970). Pengujian kandungan informasi dimaksudkan untuk melihat reaksi dari suatu pengumuman. Studi peristiwa (event study) merupakan studi yang mempelajari reaksi pasar terhadap suatu peristiwa (event) yang informasinya dipublikasikan sebagai suatu pengumuman (Hartono, 2017: 643).

Dalam pasar yang efisien, reaksi pasar atas suatu peristiwa (event) dapat digunakan sebagai indikator ada-tidaknya muatan informasi (information content) pada peristiwa tersebut. Dengan kata lain, studi peristiwa (event study) bertujuan untuk menganalisis ada-tidaknya muatan informasi yang disimpulkan berdasarkan ada-tidaknya respon pasar atas peristiwa tersebut. Brown \& Warner (1980) menyatakan bahwa studi peristiwa berfokus pada dampak dari suatu peristiwa tertentu pada harga saham sekuritas suatu perusahaan yang terkena dampak dari peristiwa tersebut.

(Griffin, 2010) menyatakan apabila suatu pengumuman mengandung informasi dan membawa sinyal berkualitas maka investor akan bereaksi. Reaksi pasar dicerminkan dengan terjadinya perubahan harga saham pada sekuritas yang bersangkutan. 


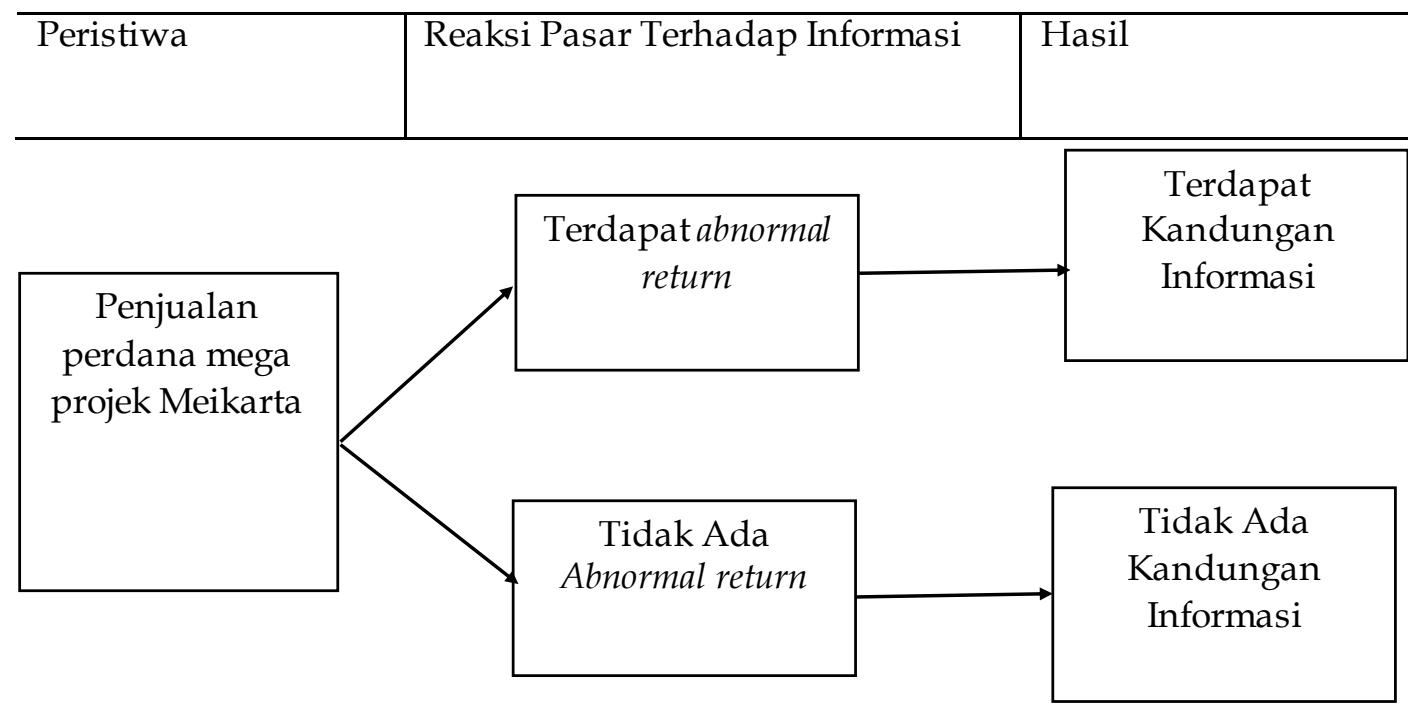

Sumber: Hartono, 2017

Gambar 2. Kandungan Informasi Suatu Peristiwa

Penjualan perdana Meikarta merupakan peristiwa yang diteliti reaksi pasarnya pada penelitian ini. Penjualan perdana pada tanggal 13 Mei 2017 mencapai jumlah 17.435 unit apartemen. Reaksi pasar yang signifikan adalah proksi untuk muatan informasi pada suatu peristiwa. Reaksi pasar dalam pengujian muatan informasi suatu pengumuman diukur dengan menggunakan return abnormal.

Istilah return dalam tulisan ini diserap secara utuh kedalam istilah Bahasa Indonesia, seperti dalam penyerapan istilah "bank," sesuai dengan penyerapan istilah yang dilakukan dalam Hartono (2017). Istilah "Istilah abnormal telah lebih dahulu diserap dan menjadi kosakata resmi Bahasa Indonesia.

Return merupakan hasil yang diperoleh dari investasi yang merupakan imbalan atas keberanian investor menanggung risiko atas investasi yang dilakukannya (Tandelilin, 2010:101) dalam (Mirayanti \& Wirama, 2017). Return dapat dibedakan menjadi return realisasian (realized return), yaitu return yang sudah terjadi dan return ekspektasian (expected return), yaitu return yang diharapkan akan diperoleh di masa mendatang. Return abnormal merupakan selisih antara return realisasian dan return ekspektasian. Return abnormal terjadi apabila suatu pengumuman mempunyai muatan informasi

Peristiwa penjualan perdana Meikarta dapat dikatakan direspon positif oleh masyarakat karena pada saat penjualan perdana tersebut sebanyak 17.435 unit apartemen berhasil terjual sehingga mengindikasikan adanya good news bagi para investor properti dan real estat. Dampak positif Meikarta ditengah lesunya pertumbuhan sektor properti dan real estat berpotensi menambah minat investor untuk berinvestasi tidak hanya pada PT Lippo Cikarang Tbk melainkan kepada semua perusahaan yang terdaftar di sektor properti dan real estat. Sehubungan dengan itu, hipotesis penelitian ini adalah sebagai berikut.

$\mathrm{H}_{1}$ : Peristiwa penjualan perdana Mega Proyek Meikarta memperoleh respon positif pada sektor properti dan real estat di Indonesia. 


\section{METODE PENELITIAN}

Penelitian ini menggunakan metode studi peristiwa (event study). Tanggal peristiwa (event date) adalah tanggal 15 Mei 2017, yaitu hari bursa pertama setelah penjualan perdana Meikarta yang berlangsung pada Sabtu, 13 Mei 2017. Jendela peristiwa (event window) terdiri atas lima hari bursa, dimulai pada dua hari sebelum sampai dengan dua hari setelah tanggal peristiwa. Return abnormal dihitung dengan menggunakan market-adjusted model. Dalam model tersebut, return ekspektasian adalah return pasar, yang diukur dengan return indeks harga saham gabungan (IHSG). Return abnormal harian dihitung selama jendela peristiwa, dan kemudian dijumlahkan untuk memperoleh return abnormal kumulatif, selanjutnya disingkat CAR (cumulative abnormal return).

$\begin{array}{lll}\mid & t_{-2}, 10 \text { Mei } 2017 & t_{-1}, 12 \\ t_{+2}, 17 \text { Mei } 2017 & t_{0}, 15 \text { Mei } 2017 & t_{+1}, 16 \text { Mei } 2017\end{array}$

Sumber: Data Penelitian, 2019

\section{Gambar 3. Jendela Peristiwa}

Sampel penelitian adalah seluruh perusahaan pada sektor properti dan real estat yang terdaftar di Bursa Efek Indonesia pada tanggal peristiwa. Penelitian dilakukan dengan mengakses data-data sekunder pada perusahaan sektor properti dan real estat yang terdaftar di Bursa Efek Indonesia (BEI) periode 2017, berupa data kualitatif yakni daftar nama perusahaan yang tergabung dalam sektor properti dan real estat yang terdaftar di Bursa Efek Indonesia (BEI) periode 2017 serta data kuantitatif yang terdiri dari daftar harga saham penutupan harian perusahaan selama periode jendela dan harga penutupan Indeks Harga Saham Gabungan (IHSG) selama periode jendela. Data nama perusahaan diperoleh dari website Bursa Efek Indonesia (www.idx.co.id). Data harga saham dan IHSG diambil dari website Yahoo!Finance (www.finance.yahoo.com).

Objek pada penelitian ini adalah abnormal return atas pengumuman penjualan perdana mega projek Meikarta pada perusahaan-perusahaan sektor properti dan real estat di Indonesia periode 2017. Penjualan perdana mega projek Meikarta merupakan variabel bebas $(X)$ atau variabel yang dapat memengaruhi variabel lainnya (Indriantoro \& Supomo, 2016: 63) sedangkan variabel terikat (Y) yang dipengaruhi variabel bebas (Indriantoro \& Supomo, 2016: 63) digambarkan reaksi pasar yang dapat dihitung dengan abnormal return. Harga saham yang digunakan adalah adjusted closing price pada tanggal yang bersangkutan.

\section{Tabel 1. Jumlah Sampel}

\begin{tabular}{lll}
\hline No & Kriteria Sampel & Jumlah \\
\hline 1 & $\begin{array}{l}\text { Perusahaan sektor properti dan real estat yang terdaftar di Bursa } \\
\text { Efek Indonesia pada tanggal peristiwa. }\end{array}$ & 52 \\
2 & $\begin{array}{l}\text { Perusahaan yang melakukan aksi korporasi (right issue, stock split, } \\
\text { merger, dan akuisisi) sepanjang periode jendela. }\end{array}$ \\
3 & $\begin{array}{l}\text { Perusahaan tidak mempunyai data lengkap yang dapat } \\
\text { mendukung penelitian serta saham tersebut aktif diperdagangkan }\end{array}$ & $(2)$ \\
selama periode jendela. & 48 \\
\hline Jumlah sampel
\end{tabular}

Sumber: Data Penelitian, 2019 
Nguyen (2014) menyatakan bahwa return abnormal harian merupakan selisih dari return realisasian dan return ekspektasian. Brown \& Warner (1985) mengemukakan terdapat tiga model estimasi untuk menghitung return ekspektasian yakni model sesuaian rata-rata (mean-adjusted model), model pasar (market model), dan model sesuaian pasar (market-adjusted model). Selanjutnya dikatakan bahwa secara umum ketiga model tersebut cenderung menghasilkan simpulan yang sama. Berikut ini adalah beberapa penelitian terdahulu yang menggunakan metode studi peristiwa.

Penelitian Dewi et. al (2018) menunjukkan terdapat reaksi positif atas peristiwa pengumuman kebijakan tax amnesty. Penelitian ini menggunakan seluruh perusahaan yang tergolong Indeks KOMPAS 100 tahun 2015 dan 2016 sebagai populasi penelitiannya. Penelitian ini menggunakan sampel sebanyak 88 perusahaan pada tahun 2015, dan 78 perusahaan pada tahun 2016. Hasil dari penelitian menunjukkan terdapat reaksi positif atas peristiwa pengumuman kebijakan tax amnesty, yang mencerminkan sensitifnya pasar modal Indonesia terhadap informasi kebijakan tax amnesty.

Septiani (2010) meneliti tentang pengaruh informasi kalah kliring bank Century terhadap harga saham pada bank konvensional yang terdaftar di bursa efek Indonesia memperoleh hasil bahwa informasi kalah kliring bank Century berpengaruh terhadap harga saham perusahaan perbankan yang terdaftar di bursa efek Indonesia.

Marisca \& Wijaya (2014) menunjukkan adanya reaksi pasar atas pengumuman kenaikan harga bahan bakar minyak. Saraswati \& Mustanda (2018), Purba \& Handayani (2017), Deva et. al (2015), Repousis (2016), Kabiru et. al (2015) dalam penelitiannya yang menguji reaksi pasar terhadap peristiwa politik menemukan bahwa terdapat reaksi positif di pasar modal yang tercermin dari adanya return abnormal di sekitar peristiwa yang diteliti.

Uygur et. al (2014) dan Wong \& Cheung (2009) memperoleh hasil bahwa terjadi perbedaan yang signifikan di hari sebelum dan sesudah peristiwa merger dan akuisisi terhadap abnormal return. Zhu \& Chen (2014), Meylita \& Yasa (2015), dan Sriram (2016) menunjukkan bahwa rata-rata return abnormal signifikan di sekitar peristiwa stock split. Penelitian yang dilakukan oleh Gajewski \& Ginglinger (2002) dan Shahid et. al (2010) menunjukkan bahwa return abnormal berbeda secara signifikan di sekitar pengumuman right issue.

Pertiwi \& Wirama (2019), menguji tentang reaksi pasar atas dividend initiation dan dividend omission dengan pengujian yang menggunakan one sample t-test memperoleh hasil pasar bereaksi negatif atas dividend omission, tetapi tidak ada reaksi atas dividend initiation. Sudewa \& Sari (2015) meneliti mengenai reaksi pasar pada saat pelaksanaan pemilihan presiden tahun 2014 dan diperoleh hasil bahwa tidak terdapat reaksi pasar pada saat pelaksanaan pemilihan presiden tahun 2014. Berdasarkan beberapa penelitian yang telah dilakukan tersebut dapat dinyatakan bahwa informasi mengenai suatu peristiwa tertentu dapat direaksi oleh pasar.

Untuk melakukan pengujian terhadap hipotesis penelitian, didahului dengan menghitung return realisasian, return ekspektasian, return abnormal, dan CAR. Return realisasian adalah return yang sebenarnya terjadi, yang dihitung dengan rumus sebagai berikut: 


$$
\mathrm{R}_{\mathrm{i}, \mathrm{t}}=\frac{p_{i, t}-p_{i, t-1}}{P_{i, t-1}}
$$

Notasi:

$\mathrm{R}_{\mathrm{i}, \mathrm{t}} \quad=$ return realisasian sekuritas ke-i pada periode ke-t.

$\mathrm{P}_{\mathrm{i}, \mathrm{t}} \quad=$ closing price hari ini.

$\mathrm{P}_{\mathrm{i}, \mathrm{t}-\mathrm{1}} \quad=$ closing price hari sebelumnya

Return ekspektasian adalah return yang diprediksi akan terjadi. Menggunakan market-adjusted model, return pasar dalam penelitian ini menggunakan return IHSG. Rumus return ekspektasian dengan market adjustedmodel adalah sebagai berikut.

$\mathrm{ER}_{\mathrm{i}, \mathrm{t}}=\frac{I H S G_{\mathrm{t}}-I H S G_{\mathrm{t}-1}}{I H S G_{\mathrm{t}-1}}$

Notasi:

$\mathrm{ER}_{\mathrm{t}} \quad=$ return ekspektasian periode $\mathrm{t}$.

$\mathrm{IHSG}_{\mathrm{t}}=$ IHSG penutupan pada hari ke $\mathrm{t}$.

$\mathrm{IHSG}_{\mathrm{t}-1}=$ IHSG penutupan pada hari ke $\mathrm{t}-1$.

Return abnormal adalah selisih return realisasian dan return ekspektasian. Rumus untuk menghitung return abnormal adalah sebagai berikut. $A R_{i, t}=R_{i, t}-E\left[R_{i, t}\right]$ Notasi:

$\mathrm{AR}_{\mathrm{i}, \mathrm{t}} \quad=$ return abnormal sekuritas ke-i pada periode ke-t.

$\mathrm{R}_{\mathrm{i}, \mathrm{t}} \quad=$ return realisasian sekuritas ke-i pada periode ke-t.

$\mathrm{E}\left[\mathrm{R}_{\mathrm{i}, \mathrm{t}}\right]=$ return ekspektasian sekuritas ke-i untuk peristiwa ke-t.

Cumulative abnormal return (CAR) yaitu penjumlahan return abnormal sepanjang jendela peristiwa. CAR dapat dihitung dengan menggunakan rumus berikut.

$\mathrm{CAR}=\sum_{t}^{T} \mathrm{AR}$

Notasi:

$\mathrm{CAR}=$ akumulasi return abnormal (cumulative abnormal return) dari periode $\mathrm{t}$ sampai $\mathrm{T}$.

$\mathrm{AR}_{\mathrm{i}, \mathrm{t}}=$ return abnormal untuk sekuritas ke-i pada hari ke-t.

Penelitian ini menggunakan teknik analisis one sample t-test. Setelah variabel-variabel tersebut diketahui maka analisis data dapat dilakukan. Sebelum menjawab hipotesis penelitian maka terlebih dahulu dilakukan pengujian normalitas. Uji normalitas adalah metode analisis data untuk melihat sebaran data atau untuk melihat tingkat kenormalan data yang akan diuji sebelum melakukan pengujian hipotesis.

Uji one sample t-test adalah salah satu uji parametrik. Tujuan pengujian menggunakan uji one sample t-test adalah untuk memperhatikan apakah di seputar peristiwa penjualan perdana mega proyek Meikarta terdapat return abnormal yang signifikan. Return abnormal yang secara statistik signifikan berarti bahwa nilainya tidak sama dengan nol (positif untuk goodnews dan negatif untuk badnews). Ketentuan dalam pengambilan keputusan mengenai penerimaan atau penolakan hipotesis dengan tingkat kepercayaan $95 \%$ atau $\alpha=$ $5 \%$. Jika nilai signifikan $\leq 0,05$ maka $\mathrm{H}_{0}$ ditolak dan $\mathrm{H}_{1}$ diterima sedangkan bila nilai signifikan $>0,05$ maka $\mathrm{H}_{0}$ diterima dan $\mathrm{H}_{1}$ ditolak. 


\section{HASIL DAN PEMBAHASAN}

Sampel semula berjumlah 48 amatan. Satu amatan teridentifikasi sebagai outlier (z-score 6,0979) dan dikeluarkan dari sampel. Statistik deskriptif CAR pada 47 perusahaan sepanjang lima hari jendela peristiwa disajikan pada Tabel 2. Nilai CAR minimum adalah -0,1642 yang terjadi pada PT Metro Realty Tbk dengan kode MTSM. Nilai maksimum CAR sebesar 0,1004 terjadi pada PT Modernland Realty Tbk dengan kode MDLN. Nilai rata-rata CAR adalah -0,0064 dengan deviasi standar 0,0495.

Tabel 2. Hasil Uji Statistik Deskriptif

\begin{tabular}{llllll}
\hline Variabel & $\mathrm{N}$ & Minimum & Maksimum & Rata-rata & $\begin{array}{l}\text { Deviasi } \\
\text { Standar }\end{array}$ \\
\hline CAR & 47 & $-0,1642$ & 0,1004 & 0,0064 & 0,0495 \\
\hline
\end{tabular}

Sumber: Data Penelitian, 2019

Tabel 3 menyajikan hasil uji normalitas. Pada tabel tersebut terlihat nilai signifikansi (asymptotic sig) dari CAR terhadap peristiwa penjualan perdana mega proyek Meikarta dengan nilai 0,083 $(>0,05)$, yang berarti data berdistribusi normal.

Tabel 3. Hasil Uji Normalitas

\begin{tabular}{llc}
\hline & & CAR \\
\hline $\mathrm{N}$ & Rata-rata & 47 \\
Normal Parameters & & $-0,0064$ \\
& Deviasi & 0,0495 \\
& standar & \\
& Absolut & 0,184 \\
Most Extreme Differences & Positif & 0,145 \\
& Negatif & $-0,184$ \\
Kolmogorov-Smirnov Z & & 1,262 \\
Asymp. Sig. (2-tailed) & & 0,083 \\
\hline
\end{tabular}

Sumber: Data penelitian, 2019

Tabel 4. menyajikan hasil one sample t-test yang menunjukkan nilai thitung sebesar -0,888 dengan nilai signifikansi sebesar 0,379, lebih besar dari a 0,05, yang berarti bahwa tidak terdapat respon pasar yang signifikan. Dengan demikian maka $\mathrm{H}_{1}$ ditolak.

Tabel 4. Hasil One Sample t-test

$\begin{aligned} & \text { Test Value }=0 \\ & \mathrm{t}\end{aligned}$
Df


adanya respon pasar yang secara statistis siginifikan. Rata-rata CAR dengan jendela tiga hari adalah -0,0012 dengan nilai t-hitung -0,259 dengan nilai probabilitas 0,796. Rata-rata CAR dengan jendela tujuh hari adalah 0,0004 dengan nilai t-hitung 0,062 nilai probabilitas 0,951.

Selama lima hari pengamatan di sekitar pengumuman penjualan perdana mega proyek Meikarta, tidak terdapat informasi yang memengaruhi nilai perusahaan. Penjualan perdana mega proyek Meikarta tersebut tidak memperoleh respon yang secara statistis signifikan di sektor properti dan real estat di Indonesia. Kemungkinan Meikarta tidak cukup sebagai indikasi akan bangkit kembalinya sektor properti dan real estat di Indonesia. Bahkan, belakangan Meikarta memperoleh publikasi negatif sehubungan dengan masalah perijinan yang berdampak pada lambatnya penyelesaian proyek.

Hasil penelitian ini sejalan dengan penelitian yang telah dilakukan sebelumnya, di antaranya Ferawati (2016) yang menyatakan bahwa Peraturan Menteri Perhubungan Nomor 32 Tahun 2016 Tanggal 28 Maret 2016 tidak direspon oleh pasar, meskipun peraturan tersebut diperkirakan akan memengaruhi perusahaan pada sub sektor transportasi darat. Aditya (2016) juga menunjukkan hasil bahwa tidak terdapat respon pasar yang signifikan pada sub sektor properti dan real estat atas kebijakan penurunan suku bunga Bank Indonesia, padahal kebijakan tersebut diperkirakan akan membantu peningkatan penjualan properti.

Penelitian ini dapat digunakan sebagai sumber dan pembanding, serta referensi bagi penelitian berikutnya yang berhubungan dengan riset muatan informasi dan teori efisiensi pasar khususnya yang menjelaskan mengenai efisiensi pasar terhadap suatu informasi. Implikasi praktis dari penelitian ini adalah bahwa para pelaku pasar selalu harus berhati-hati dalam menyikapi berbagai peristiwa yang dipublikasi sebelum mengambil keputusan investasi. Seperti yang ditunjukkan melalui penelitian ini, peristiwa besar dan memperoleh publikasi luas tidak selalu memiliki muatan informasi yang memengaruhi nilai perusahaan.

\section{SIMPULAN}

Hasil analisis data menunjukkan tidak adanya respon pasar atas penjualan perdana mega proyek Meikarta, sehingga disimpulkan bahwa penjualan perdana Meikarta tidak memiliki muatan informasi yang memengaruhi nilai perusahaan pada sektor properti dan real estat di Indonesia. Sehubungan dengan itu maka disarankan agar investor lebih cermat dalam menilai setiap peristiwa yang terjadi karena tidak semua peristiwa memiliki muatan informasi meskipun peristiwa dipublikasi secara besar-besaran dan menyita perhatian publik.

Dalam penelitian ini, uji sensitivitas telah dilakukan untuk jendela peristiwa yang lebih pendek dan lebih panjang dengan hasil yang konsisten. Penelitian selanjutnya dapat mempertimbangkan untuk menggunakan model perhitungan return abnormal yang berbeda untuk menambah tingkat keyakinan atas simpulan penelitian ini. 


\section{REFERENSI}

Aditya, R. (2016). Analisis Reaksi Pasar Modal Terhadap Pengumuman Kebijakan Penurunan BI Rate.

Brown, S. J., \& Warner, J. B. (1980). Measuring Security Price Performance. Jurnal of Financial Economics, 8(3), 205--258.

Brown, S. J., \& Warner, J. B. (1985). Using Daily Stock Returns. Jurnal of Financial Economics, 14, 3-31.

Deva B, K., Sharon, S., \& Maria, J. E. (2015). Empirical Study on Effects of the Lok Sabha Election on Stock Market Performance (BSE SENSEX). Research Journal of Management Sciences, 4(2), 1-9.

Dewi, I. G. A. A. P., Wirama, D. G., \& Sari, M. M. R. (2018). Reaksi Pasar Modal atas Kebijakan Tax Amnesty. Jurnal Buletin Studi Ekonomi, 23(2), 6176.

Fama, E. F. (1970). Efficient Capital Markets : A Review of Theory and Empirical Work. Journal of Finance, 25(2), 1-36.

Ferawati. (2016). Analisis Studi Peristiwa Pengaruh Peraturan Menteri Perhubungan Nomor 32 Tahun 2016 Terhadap Kinerja Saham Perusahaan Sub Sektor Transportasi. universitas gadjah mada.

Fitra, S. (2015). Sektor Properti Terimbas Daya Beli Yang Rendah. Katadata.Co.Id. Retrieved from https://katadata.co.id/berita/2015/06/16/sektorproperti-terimbas-daya-beli-yang-rendah

Foster, G. (1986). Financial Statement Analysis (second edi). New Jersley: Prentice Hall- Internattional Inc.

Gajewski, J.-F., \& Ginglinger, E. (2002). Seasoned Equity Issues in a Closely Held Market: Evidence from France. Review of Finance, 6(3), 291-319. https://doi.org/10.1023/a:1022024925877

Griffin, C. H. (2010). Abnormal Returns and Stock Splits: The Decimalized vs. Fractional System of Stock Price Quotes. International Journal of Business and Management, 5(12), 3-13. https://doi.org/10.5539/ijbm.v5n12p3

Hartono, J. (2017). Teori Portofolio dan Analisis Investasi. Yogyakarta: BPFE.

Himawan, A. (2017). Launching Perdana Meikarta, 16.800 Unit Properti Telah Dipesan. Suara.Com, p. 1. Retrieved from https://www.suara.com/bisnis/2017/05/14/134411/launcingperdana-meikarta-16800-unit-properti-telah-dipesan

Indriantoro, N., \& Supomo, B. (2016). Metode Penelitian Bisnis Untuk Akuntansi Dan Manajemen (pertama). Yogyakarta: BPFE.

Kabiru, J. N., Elly, D., Hellen, O., \& Kinyua, W. (2015). The Effect Of General Elections On Stock Returns At The Nairobi Securities Exchange. European Scientific Journal, 11(28): 43.

Lutfiana, I. (2018). Iklan Meikarta Versi "Aku Ingin Pindah ke Meikarta."

Marisca, E., \& Wijaya, T. (2014). Analisis Perbedaan Abnormal Return Sebelum dan Sesudah Pengumuman Kenaikan Harga Bahan Bakar Minyak (BBM) di Perusahaan LQ45. E-Jurnal Manajemen STIE Multi Data Palembang, 1-10.

Mayanti, D. (2018). Proyek Pembangunan Kota Meikarta dalam Perspektif Etika Bisnis. Skripsi. 
Meylita P, H., \& Gerianta Y, W. (2015). Perbedaan Reaksi Pasar Atas Pengumuman Pemecahan Saham Pada LQ45 Dan Non LQ45. Jurnal Ilmiah Akuntansi Dan Bisnis, 10(2), 96-104.

Mirayanti, N. M., \& Wirama, D. G. (2017). Pengaruh Variabel Ekonomi Makro Pada Return Saham Lq45 Di Bursa Efek Indonesia. E-Jurnal Akuntansi Universitas Udayana, 21(1), 505-533.

Nguyen, K. H. (2014). Impact of a Devidend Initiation Wave on Shareholders' Wealth. Applied Financial Economics, Forthcoming, 24(8), 5573-5586.

Pertiwi, N. P. A., \& Wirama, D. G. (2019). Reaksi Pasar atas Deviden Initiation dan Deviden Omission. E-Jurnal Akuntansi Universitas Udayana, 26(2), 1190-1214.

Purba, F., \& Handayani, S. R. (2017). Analisis Perbedaan Reaksi Pasar Modal Indonesia Sebelum Dan Sesudah Peristiwa Non Ekonomi. Jurnal Administrasi Bisnis (JAB), 51(1), 115-123.

Repousis, S. (2016). Stocks' Prices Manipulation Around National Elections?: An Event Study for The Case of Greek Banking Sector. Journal of Financial Crime, 23(2), 248-25.

Saraswati, N. M. A. W., \& Mustanda, I. K. (2018). Reaksi Pasar Modal Indonesia Terhadap Peristiwa Pengumuman Hasil Penghitungan Suara Pemilihan Umum dan Pelantikan Presiden Amerika Serikat. E-Jurnal Manajemen Unud, 7(6), 2971-2998.

Septiani, Y. (2010). Informasi Kalah Kliring Bank Century terhadap Harga Saham pada Bank Konvensional yang Terdaftar di Bursa Efek Indonesia. Skripsi. Universitas Islam Negeri Sultan Syarif Kasim Kasim Pekanbaru.

Shahid, H., Xia, X., Mahmood, F., \& Usman, M. (2010). Announcement Effects of Seasoned Equity Offerings in China. International Journal of Economics and Finance, 2(3), 163-169. https://doi.org/10.5539/ijef.v2n3p163

Sriram, M. (2016). Empirical Evidence of Market Reaction to Stock Splits. Shri Dharmasthala Manjunatheshwara Institute for Management Development, 165-184.

Sudewa P, D. G. O., \& Sari, M. M. R. (2015). Reaksi Pasar Atas Peristiwa Pilpres 2014. E-Jurnal Akuntansi Universitas Udayana, 12(3), 465-480.

Uygur, O., Meric, G., \& Meric, I. (2014). Market Reaction to Acquisition Announcements After the 2008 Stock Market Crash. The International Journal of Business and Finance Research, 8(4), 75-82.

Watts, R. L., \& Zimmerman, J. L. (1986). Positive Accounting Theory. New Jersey: Prentice Hall, Inc.

Wong, A., \& Cheung, K. Y. (2009). The Effects of Merger and Acquisition Announcements on the Security Prices of Bidding Firms and Target Firms in Asia. International Journal of Economics and Finance, 1(2), 274283.

Zhu, C., \& Chen, K. (2014). The Market Reaction to Stock Split Announcement and The Underlying Explanations. SFU Summit Institutional Repository.

Ziobrowski, A. J., Boyd, J. W., Cheng, P., \& Ziobrowski, B. J. (2011). Abnormal returns from the common stock investments of Members of the U.S. 
House of Representatives. Business and Politics. https://doi.org/10.2202/1469-3569.1308 